\title{
PENGARUH TERAPI MASSAGE PUNGGUNG TERHADAP PENINGKATAN KUALITAS TIDUR PADA LANSIA DI PANTI JOMPO YAYASAN GUNA BUDI BAKTI MEDAN TAHUN 2020
}

\author{
${ }^{1}$ Hajrah Ainun, ${ }^{2}$ Gregorius Benard Ndruru, ${ }^{3}$ Krisna Yuliriska Baeha, ${ }^{4}$ Sunarti \\ ${ }^{1,2,3}$ Program Studi S-1 Keperawatan, Universitas Prima Indonesia, Indonesia \\ ${ }^{4}$ Program Studi Profesi Ners, Universitas Prima Indonesia, Indonesia \\ Email: ${ }^{1}$ hajrahainun45@gmail.com, ${ }^{2}$ gregoriusbenardndruru22@gmail.com, ${ }^{3}$ riskabaeha@yahoo.com, \\ ${ }_{4}^{4}$ sunartibiomed@gmail.com
}

\begin{abstract}
ABSTRAK
Kualitas tidur merupakan suatu pertahanan maupun kemampuan seseorang untuk memepertahankan kondisi tidurnya agar mempunyai kualitas kebutuhan tidur yang dapat disesuaikan dengan tidur yang diperlukan. Pada lansia umumnya memiliki kualitas tidur sudah menurun, maka digunakan pengobatan komplementer yaitu massage punggung untuk meningkatkan derajat kesehatan yaitu meningkatkan kualitas tidur. Tujuan penelitian ini untuk meningkatkan kualitas tidur lansia sebelum dan sesudah dilakukan terapi massage punggung. Jenis penilitian ini yaitu quasi experiment dengan menggunakan rancangan pretest dan posttest yang dilaksanakan di Panti Jompo Yayasan Guna Budi Bakti Medan. Jumlah sampel sebanyak 20 orang responden. Alat pengumpulan data yang digunkan dalam penelitian ini menggunakan kuesioner KSPBJ untuk mengukur kualitas tidur pada lansia dan menggunakan instrumen SOP massage punggung. Uji yang digunakan yaitu Wilcoxon Rank Test. Hasil penelitian menunjukkan bahwa ada peningkatan kualitas tidur dengan nilai $p$ value $=0,000(p<0,05)$ sebelum dan sesudah dilakukan terapi massage punggung. Kesimpulan penelitian ini yaitu terapi massage punggung memberikan pengaruh pada lansia di Panti Jompo Yayasan Guna Budi Bakti Medan terhadap peningkatan kualitas tidur. Disarankan kepada lansia dapat mengaplikasikan atau menggunakan terapi massage punggung ini dengan bantuan perawat di Panti Jompo Yayasan Guna Budi Bakti Medan sebagai salah satu penatalaksanaan mengatasi penurunan kualitas tidur yang diderita oleh lansia tersebut.
\end{abstract}

Kata kunci : Kualitas Tidur, Massage punggung, Lansia.

\section{ABSTRACT}

Sleep quality is both a defense and the ability of a person to maintain his sleep conditions in order to have the quality of sleep needs that can be adjusted to the sleep needed. In the elderly generally have decreased sleep quality, then used complementary medicine that is back massage to improve the degree of health that is improving sleep quality. The purpose of this study is to improve the quality of sleep in the elderly before and after back massage therapy. This type of research is a quasi experiment using a pretest and posttest design that is carried out at the Nursing Home Foundation Guna Budi Bakti Medan. The number of samples were 20 respondents. The data collection tool used in this study uses the KSPBJ questionnaire to measure sleep quality in the elderly and uses a back massage SOP instrument. The test used is the Wilcoxon Rank Test. The results showed that there was an increase in sleep quality with a $p$ value $=0,000(p<0.05)$ before and after back massage therapy. The conclusion of this study is that back massage therapy has an influence on the elderly in the Nursing Home Foundation Budi Guna Bakti Medan to improve sleep quality. It is recommended that the elderly can apply or use this back massage therapy with the help of nurses at the Nursing Home Foundation Budi Guna Bakti Medan as one of the treatments to overcome the decline in sleep quality suffered by the elderly.

Keywords: Sleep Quality, Back Massag, Elderly.

\section{PENDAHULUAN}

Tidur merupakan suatu kegiatan otak secara relatif tanpa sadar dapat menimbulkan situasi yang penuh dengan ketenangan dan tanpa adanya kegiatan sehingga terjadinya susunan masa secara bergantian atau berulang-ulang dan memiliki periode yang berbeda-beda, kualitas tidur yang efektif kurang lebih 6 jam perhari (Tarwoto dan Wartonah, 2010). 
Kualitas tidur merupakan suatu pertahanan maupun kemampuan seseorang untuk memepertahankan kondisi tidurnya agar mempunyai kualitas kebutuhan tidur yang dapat disesuaikan dengan tidur yang diperlukan, adapun mayoritas dari sebagian lansia di Dusun Joho Desa Condongcatur Depok Sleman mempunyai kualitas tidur lansia yang jelek atau buruk dan mempunyai waktu tidur yang singkat sehingga ketika bangun tidur lansia masih merasa ngantuk, yaitu terdapat 41 responden dengan hasil persentase 58,6\% lansia yang mempunyai kualitas tidur buruk (Hidayat, 2016).

Pada lansia umumnya memiliki kualitas tidur sudah menurun. Hal ini menjadi masalah kesehatan pada lansia karena di negara Indonesia termasuk memiliki jumlah lansia yang tinggi mencapai 22,4 juta orang atau seimbang atau sejajar dengan $8,69 \%$ dari jumlah seluruh penduduk Indonesia (Kemenkes, 2018).

Berdasarkan statistik penduduk lanjut usia (lansia) Provinsi Sumatera Utara, Tahun 2017 total lansia sebesar 7,25\% dari total seluruh lansia yang ada di Sumatera Utara, yang dimana terjadi peningkatan jumah lansia pada tahun sebelumnya dari $6,96 \%$ menjadi $7,25 \%$ yaitu bertambah $0,29 \%$, dari jumlah tersebut Sumatera Utara terbilang kedalam kawasan atau daerah dengan morfologi penduduk menyusul atau menuju tua (ageing population).

Hasil penelitian (Farazdag, 2018) terdapat beberapa faktor yang terkait dengan insomnia yang terjadi pada lansia seperti bertambanhnya usia, jenis kelamin, status pernikahan, status pekerjaan, pendapatan rata-rata perbulan, tingkat pendidikan, dan BMI (indek massa tubuh) yang tidak terlalu mempengeruhi secara signifikan, dan dalam penelitiannya ini juga terdapat beberapa gejala yang dapat mempengaruhi terjadinya insomnia pada lansia terdiri dari $12,5 \%$ memiliki satu gejala, 34,4\% memiliki dua gejala, 31,3\% memiliki 3 gejala, dan 21,9\% memiliki empat gejala insomnia pada lansia. Di Indonesia sendiri lansia yang mengalami insomnia berkisar antara $25,5 \%$ dan $34,8 \%$.

Hasil penelitian (Nasution, 2016) yang menjadi penyebab terjadinya kejadian insomnia pada lansia berdasarkan tidur siang yang berlebihan pada lansia, gaya hidup (seperti merokok, mengkonsumsi alkohol, minum kopi, obat penurun berat badan, dan jam kerja yang tidak teratur), masalah psikiatri (gangguan jiwa), faktor psikologis (stress yang berkepanjangan), sakit fisik (asma, sinusitis, dan flu), serta faktor lingkungan (suara TV yang keras, lingkungan disekitar lintasan pesawat terbang, lintasan kereta api, dan pabrik).

Berdasarkan survey awal yang dilakukan peneliti di Panti Jompo Yayasan Guna Budi Bakti Medan didapatkan data dari ketua penanggung jawab dan perawat Panti Jompo, jumlah lansia dalam tahun ini sebanyak 74 orang. Dimana dengan jumlah lansia yang berjenis kelamin laki-laki sebanyak 31 orang dan lansia yang berjenis kelamin perempuan sebanyak 43 orang. Terdapat berbagai gejala dialami lansia yang mengalami penurunan kualitas tidur antara lain : badan terasa lemah, letih, kurang tenaga, gelisah, sakit kepala pada siang hari, wajah tampak pucat dan merasa mengantuk disiang hari.

Dengan bertambahnya usia serta terjadinya proses penuaaan akan mempengaruhi waktu dan kualitas tidur seseorang, terutama pada usia tua yang akan mengalami degenerasi sel serta organ yang dapat memberikan pengaruh terhadap fungsi dan mekanisme tidur. Salah satu yang dapat mempengaruhi tidur yaitu usia, status kesehatan, lingkungan, motivasi, stres psikologis, diet, gaya hidup, dan obat-obatan (Aspiani, 2014).

Terapi komplementer dapat menggunakan intervensi tubuh berupa meningkatkan kualitas tidur. Massage punggung merupakan suatu sentuhan tangan yang dilakukukan dengan cara gerakan stroking, petrisage, friction dan skin rolling yang bertujuan untuk mengatasi gejala insomnia, mengurangi keluhan pada berbagai macam masalah kesehatan yang berindikasi untuk diberikannya pijatan tanpa memasukkan obat keadaan tubuh (Wiyoto, 2011).

Hasil penelitian (Faishal, 2016) pola tidur pada lansia umumnya memiliki perbedaan, dengan begitu yang membedakannya adalah sikap dan cara lansia melakukan kegiatan ataupun aktivitas sebelum tidur, meskipun lansia memiliki cara sendiri untuk memperoleh tidur yang akan menyegarkan tubuhnya, biasanya tidur lansia antara 4 sampai 5 jam perhari. Adapun 
gangguan lain yang dapat mempengaruhi kualitas tidur lansia yaitu stress dan depresi, dikarenakan umur yang sudah tua lansia dapat dengan mudahnya mengalami stress dan depresi.

Hasil penelitian (Abdel, dkk, 2017) mengambil responden dengan usia berkisar antara 60 sampai 91 tahun yaitu lansia yang mengalami insomnia dapat dikategorikan menjadi beberapa komponen yaitu jenis kelamin, penyakit yang diderita lansia, inkontenensia pada lansia, keadaan kamar dengan banyaknya masuk angin, lansia yang takut akan kematian, memikirkan anak, tanggung jawab/tugas, mimpi buruk serta depresi yang dialami lansia.

Hasil penelitian (Rizkiani, 2018) membagi lansia menjadi beberapa karakteristik yaitu berdasarkan jenis kelamin, umur, agama dan status pendidikan yang berjumlah 11 orang dengan kualitas tidur agak buruk, namun setelah dilakukan terapi massage punggung kualitas tidur lansia menjadi agak baik dengan $p$ value 0,003 yang berarti ada pengaruh pemberian terapi massage punggung terhadap peningkatan kualitas tidur lansia di Balai Pelayanan Sosial Tresna Werdha Unit Budi Luhur Kasongan Bantul Yogyakarta.

Hasil penelitian (Murti, 2015) massage dapat menstimulasi morphin endogen yaitu hormon endorphin, enkefalin, dan dinorfin serta dapat menimbulkan adanya relaksasi pada otot, yang berfungsi sebagai meningkatkan kualitas dan kuantitas tidur, mempercepat proses tidur, dan dapat membantu menurunkan gejala gangguan tidur pada lansia. Dengan timbulnya hormon tersebut saat setelah dilakukan massage atau massase pada lansia yang mengalami insomnia atau gangguan tidur akan dapat meningkatkan serta menambah kualitas dan kuantitas tidur lansia.

Massage punggung merupakan suatu sentuhan tangan yang dilakukukan dengan cara gerakan stroking, petrisage, friction dan skin rolling yang bertujuan untuk mengatasi gejala penurunan kualitas tidur, mengurangi keluhan pada berbagai macam masalah kesehatan yang berindikasi untuk diberikannya pijatan tanpa memasukkan obat keadaan tubuh (Wiyoto, 2011).

Berdasarkan paparan yang ada diatas peneliti terdorong dan tertarik untuk melaksanakan penelitian tentang "Pengaruh

Terapi Massage Punggung Terhadap Peningkatan Kualitas Tidur Pada Lansia Di Panti Jompo Yayasan Guna Budi Bakti Medan Tahun 2020".

\section{METODE}

Tujuan penelitian ini untuk meningkatkan kualitas tidur lansia sebelum dan sesudah dilakukan terapi massage punggung. Penelitian ini menggunkan metode kuasi eksperimen (Quasi eksperiment), dengan rancangan penetitian yaitu rancangan pre-test dan post-test group design. Populasi dari penelitian yaitu seluruh atau semua lansia yang ada di Panti Jompo Yayasan Guna Budi Bakti Medan dengan menggunkan metode purposive sampling sebanyak 74 orang responden. Dan dengan jumlah sampel 20 orang responden berdasarkan kriteria inklusi (lansia atau responden yang mengalami insomnia atau gangguan tidur, menderita penurunan kualitas tidur, lansia yang bersedia menjadi responden penelitian, mampu melakukan interaksi dan komunikasi dengan baik) serta kriteria eksklusi (lansia yang tidak berada di Panti Jompo, lansia yang menolak dalam pemberian terapi massage punggung, lansia yang mempunyai kontra indikasi pemberiaan massage punggung seperti fraktur tulang rusuk, luka bakar, luka terbuka pada area punggung, tidak mampu berinteraksi dan berkomunikasi dengan baik).

Tindakan terapi massage punggung dilakukan 2 kali tindakan dengan durasi 30 menit selama 1 minggu. Pengambilan data dilakukan sebelum dan sesudah tindakan, langsung dari lansia atau responden dengan menggunkan pengisian kuesioner KSPBJ (IRS-Insomnia Rating Scale) (Iwan, 2009) dan hasil penjumlahan hasil kuesioner dengan pernyataan sebanyak 10 poin (dengan jumlah keseluruhan pernyataan dikategorikan dengan nilai skor 10-40 poin, dimana dengan jumlah 10-18 = kualitas tidur sangat baik, 19-26 = kualitas tidur cukup baik, 27-35 = kualitas tidur cukup buruk, dan 36-40 = kualitas tidur sangat buruk (Iwan, 2009). Analisis data menggunakan uji Wilcoxon Rank test. 
3. HASIL DAN PEMBAHASAN

\subsection{Hasil}

Tabel 1. Distribusi Frekuensi Sebelum

Dilakukan Terapi Massage Punggung

Terhadap Peningkatan Kualitas Tidur Di

Panti Jompo Yayasan Guna Budi Bakti Medan Tahun 2020

\begin{tabular}{llcc}
\hline No & $\begin{array}{l}\text { Kualitas Tidur Pre } \\
\text { Test }\end{array}$ & $\begin{array}{c}\text { Jumlah } \\
(\mathbf{n})\end{array}$ & $\begin{array}{c}\text { Persentase } \\
(\%)\end{array}$ \\
\hline 1 & $\begin{array}{l}\text { Kualitas tidur } \\
\text { sangat baik }\end{array}$ & - & - \\
\hline 2 & $\begin{array}{l}\text { Kualitas tidur cukup } \\
\text { baik }\end{array}$ & 2 & 10 \\
\hline 3 & $\begin{array}{l}\text { Kualitas tidur cukup } \\
\text { buruk }\end{array}$ & 8 & 40 \\
\hline 4 & $\begin{array}{l}\text { Kualitas tidur } \\
\text { sangat buruk }\end{array}$ & 10 & 50 \\
\hline Total & $\mathbf{2 0}$ & $\mathbf{1 0 0}$ \\
\hline
\end{tabular}

Berdasarkan dari paparan hasil tabel 1 diatas dapat diamati bahwa kualitas tidur lansia sebelum dilakukan terapi massage punggung dari 20 responden yang memiliki kualitas tidur sangat buruk dengan jumlah 10 responden $(50 \%)$ atau separuh dari jumlah responden.
Tabel 2. Distribusi Frekuensi Setelah

Dilakukan Terapi Massage Punggung

Terhadap Peningkatan Kualitas Tidur Di

Panti Jompo Yayasan Guna Budi Bakti Medan Tahun 2020

\begin{tabular}{llcc}
\hline No & $\begin{array}{l}\text { Kualitas Tidur Pre } \\
\text { Test }\end{array}$ & $\begin{array}{c}\text { Jumlah } \\
(\mathbf{n})\end{array}$ & $\begin{array}{c}\text { Persentase } \\
(\mathbf{\%})\end{array}$ \\
\hline 1 & $\begin{array}{l}\text { Kualitas tidur sangat } \\
\text { baik }\end{array}$ & 9 & 45 \\
\hline 2 & $\begin{array}{l}\text { Kualitas tidur cukup } \\
\text { baik }\end{array}$ & 4 & 20 \\
\hline 3 & $\begin{array}{l}\text { Kualitas tidur cukup } \\
\text { buruk }\end{array}$ & 5 & 25 \\
\hline 4 & $\begin{array}{l}\text { Kualitas tidur sangat } \\
\text { buruk }\end{array}$ & 2 & 10 \\
\hline & Total & $\mathbf{2 0}$ & $\mathbf{1 0 0}$ \\
\hline & Berdasarkan dari hasil paparan tabel 2
\end{tabular}

Berdasarkan dari hasil paparan tabel 2 diatas dapat diamati bahwa kualitas tidur lansia setelah dilakukan terapi massage dari 20 orang responden mayoritas yang memiliki atau mempunyai kualitas tidur sangat baik dengan total 9 orang responden $(45 \%)$.

Tabel 3. Peningkatan Kualitas Tidur Lansia yang Menjalani Terapi Massage Punggung Di Panti Jompo Yayasan Guna Budi Bakti Medan Tahun 2020

\begin{tabular}{lccccc}
\hline Kualitas Tidur & $\boldsymbol{n}$ & Mean & Std. Deviation & $\boldsymbol{Z}$ & $\boldsymbol{P}$-value \\
\hline Pre Test & 20 & 3,40 & 0,681 & $-3921^{\mathrm{b}}$ & 0,000 \\
\hline Post Test & 20 & 2,00 & 1,076 & & \\
\hline
\end{tabular}

Berdasarkan dari hasil paparan tabel 3 diatas dapat diamati bahwa dari 20 responden lansia yang menderita penurunan kualitas tidur dengan signifikan 0,05 atau 5\%. Dari hasil paparan perhitungan wilcoxon signed rank test nilai atau total $\mathrm{Z}=-3,921^{\mathrm{b}}$ dengan nilai atau total $p$ value $0,000<0,05$ sehingga Ha diterima da Ho ditolak. Dapat disimpulkan bahwa ada peningkatan kualitas tidur secara signifikan pada lansia yang menderita penurunan kualitas tidur dengan terapi massage punggung di Panti Jompo Yayasan Guna Budi Bakti Medan Tahun 2020.

\subsection{Pembahasan}

Pada umumnya kualitas tidur lansia (lanjut usia) yang mengalami penurunan kualitas tidur sebelum dilakukan terapi massage punggung mengalami kualitas tidur sangat buruk, berikut ini dapat berdampak bagi lansia sehingga dapat menimbulkan badan terasa lemah, letih, kurang tenaga, gelisah, sakit kepala pada siang hari, wajah tampak pucat dan merasa mengantuk disiang hari. Sehingga peningkatan kualitas tidur pada lansia yang mengalami penurunan kualitas tidur menjadi prioritas utama peneliti dalam keperawatan.

Berdasarkan dari hasil penelitian (Juwita, dkk, 2019) dengan total subjek responden sebanyak 34 orang responden, sebelum dilakukan massage memperlihatkan bahwa dari sebagian besar responden mempunyai insomnia sedang sebanyak 24 orang $(70,59 \%)$ dan 10 orang mengalami insomnia ringan $(29,41 \%)$, sedangkan setelah dilakukan massage menunjukkan bahwa insomnia sedang 4 orang $(11,76 \%), 24$ orang (70,59\%) memiliki insomnia ringan dan untuk normal 6 orang $(17,65 \%)$.

Penelitian sebelumnya yang dilakukan (Deviana, 2018) mengatakan bahwa adanya pengaruh yang secara signifikan pengaruh 
massage therapy pada daerah punggung dengan nilai hasil total $p$ value $=0,006$ dimana $p=<0,05$, sehingga didapatkan ditarik kesimpulan bahwa adanya pengaruh massage therapy pada kualitas tidur lansia.

Penelitian ini sependapat dengan hasil penelitian (Zulmi, 2016) berdasarkan pengaruh masase punggung pada kualitas tidur lansia yang menerima dan menjalani masase punggung dengan hasil nilai uji statistik memperlihatkan bahwa terdapat pengaruh yang signifikan antara masase punggung kepada kualitas tidur lansia.

Menurut hasil dari penelitian yang dilaksanakan oleh (Mailisna, dkk, 2019) dengan mengatakan ada perbedaan antara atau jarak kualitas tidur sebelum secara keseluruhan dan sesudah tindakan back massage dilakukan dengan nilai $p$ value $=$ 0,000 dan total std. deviation pre test yaitu 4,703 sedangkan post test yaitu 3, 825 dan hasil mean pre test $=9,39$ serta hasil mean post test $=13,51$.

Berdasarkan dari nilai hasil total penelitian sebelumnya yang dilaksanakan oleh Afianti dan Ai, 2017 massage therapy adalah suatu cara yang dapat dilakukan untuk meningkatkan rasa rileks pada bagian yang dipijat dan juga merupakan terapi komplementer yang digunakan untuk meningkatkan kualitas tidur, dengan total nilai signifikan $\mathrm{P}$ value yaitu $0,002(P<0,05)$, dilakukan sebelum tidur selama 2 hari berturutan dengan rentang waktu 10 menit.

Terapi massage punggung merupakan suatu tindakan mengurut atau memijat suatu daerah yaitu punggung, yang dilakukan dengan penekanan yang tidak kuat pada kulit dan usapan dengan ringan dipusatkan dibagian telapak tangan yang bertujuan untuk menghilangkan atau mengurangi keluhan dan dapat meningkatkan kualitas tidur (Wiyoto, 2011).

Menurut asumsi peneliti berdasarkan dari nilai hasil penelitian yang sudah dilaksanakan diketahui ada pengaruh yang sangat signifikan antara terapi massage punggung dengan peningkatan kualitas tidur lansia yang menderita insomnia atau kesulitan tidur. Dalam hal ini juga adalah salah satu intevensi non farmakologi yang dapat dilaksanakan perawat lansia secara mandiri dalam meningkatkan kualitas tidur lansia, yaitu dengan melakukan tindakan terapi massage punggung pada lansia yang mengalami insomnia atau kesulitan tidur untuk meningkatkan kualitas tidur yang dialami oleh lansia atau responden.

Berdasarkan dari hasil penelitian yang dilakukan oleh (Dionesia, 2017) tentang efektifitas tindakan massage dalam memenuhi kualitas tidur pada lansia yaitu sebanyak 10 responden dengan total nilai pre test 12,10 dan nilai total post test 4,60 yang menunjukkan nilai signifikan $\mathrm{p}$ value $=$ 0,125 , setelah diberikan tindakan massage selama 1 minggu dengan waktu 20 menit menggunkan kuesioner berupa sarana atau alat ukur Pittsburgh Sleep Quality Index (PSQI), didapatkan total hasil nilai bahwa yaitu semua responden mengalami kualitas tidur baik.

\section{KESIMPULAN}

Ada pengaruh terapi massage punggung terhadap peningkatan kualitas tidur pada lansia di Panti Jompo Yayasan Guna Budi Bakti Medan Tahun 2020.

\section{REFERENCES}

Abdel, dkk. 2017. Prevalence of Insomnia and its Associated Factors Among Rural Elderly: a Community Based Study. SPC, 6(1), 54-62. Diakses dari https://www.sciencepubco.com/index.ph p/IJANS/article/view/7415.

Afianti dan Ai, 2017. pengaruh foot massage terhadap kualitas tidur pasien, UP 5(1), 86-97. Diakses dari http://jkp.fkep.unpad.ac.id/index.php/jkp article/view/353.

Aspiani, RY. 2014. Buku Ajar Asuhan Keperawatan Gerontik Aplikasi Nanda, NIC dan NOC, Jilid 2. Jakarta : TIM

Badan Pusat Statistik. 2017. Statistik Penduduk Lanjut Usia Provinsi Sumatera Utara. Sumatera Utara: Rilis Grafika, 19-27. Diakses dari https://sumut.bps.go.id/publication/2018/ 09/12/a67f499cc590ab51b8c0e65b/statis tik-penduduk-lanjut-usia-provinsisumatera-utara-2017.html.

Deviana, SU, 2018. Perbedaan Pengaruh Foot Reflexology Dan Massage Therapy Terhadap Kualitas Tidur Pada Lansia, UMS, 1-10. Diakses dari http://eprints.ums.ac.id/66233/11/Naska h\%20Publikasi\%20baru.pdf. 
Dionesia, EA, 2017. Perbedaan Efektivitas Tindakan Massage Dan Pemberian Rendan Air Hangat Dalam Memenuhi Kualitas Tidur Pada Lansia, SSBB, 111118. Diakses dari http://ojs.itekesbali.ac.id/index.php/jrkn/article/view/79.

Faishal, H. 2016. Pola Tidur dan Kesehatan Jasmani Lansia, Studi Deskriptif Pada Lansia di Panti Werdha Usia Surabaya, UA, 1-13. Diakses dari http://repository.unair.ac.id/68145/3/Fis. S.17.17\%20.\%20Haq.p\%20\%20JURNAL.pdf.

Farazdag H, Andreas M and Nanji K. 2018. Insomnia and its Correlates among Elderly Patients Presenting to Family Medicine Clinics at an Academic Center. Journal Original Artcle, 13(3), 12-19. Diakses dari https://www.ncbi.nlm.nih.gov/pmc/articl es/PMC6382090/.

Hidayat, NAH. 2016. Hubungan Tingkat Stres dengan Kualitas Tidur Lansia di Dusun Joho Desa Condong Catur Depok Sleman, SJY, 1-60. Diakses dari http://repository.unjaya.ac.id/584/.

Iwan. 2009. Skala Insomnia (KSPBJ Insomnia Rating Scale). http://www.sleepnet.com.

Juwita, dkk, 2019. Perbedaan Efektivitas Tindakan Massage Dan Pemberian Rendan Ajurnal Pengaruh Massage Wajah (Pijat Wajah) Terhadap Insomnia Pada Pralansia, 137-146. Diakses dari Https://Jurnalskhg.Ac.Id/Index.Php/Med ika/Article/View/115.

Kemenkes RI. 2018. Lansia sejahtera, masyarakat bahagia. Ministry Of Health Republic of Indonesia, 1-2. Diakses dari https://www.depkes.go.id/article/view/1 8050900001/lansia-sejahteramasyarakat-bahagia-.html.
Mailisna, dkk, 2019. Perbedaan Terapi Back Massage dan Akupresur Terhadap Kualitas Tidur Pasien Hemodialisa, JPPNI 1(3), 217-222. Diakses dari http://www.jurnalppni.org/ojs/index.php/jppni/article/view 132.

Murti, WN. 2015. Efek Circulo Massage Terhadap Gangguan Tidur pada Wanita Lansia di Posyandu Lansia Cebongan Ngestiharjo Kasihan Bantul, 1-9. Diakses dari http://journal.student.uny.ac.id/ojs/index. php/ikora/article/view/7546.

Nasution, BH. 2016. Faktor-faktor yang Mempengaruhi Terjadinya Insomnia pada Lansia di Samanhudi Kelurahan Estate Kecamatan Binjai Selatan, 77-83. Diakses dari https://jurnal.kesdammedan.ac.id/index. php/jurhesti/article/view/66.

Rizkiana, J. 2018. Pengaruh Terapi Massage Punggung Terhadap Kualitas Tidur Lansia di Balai Pelayanan Sosial Tresna Werdha Unit Budi Luhur Kasongan Bantul Yogyakarta. UA. Diakses dari http://digilib.unisayogya.ac.id/4363/1/N ASKAH\%20PUBLIKASI\%20JANY\%2 ORIZKIANA\%20201410201091.pdf.

Tarwoto \& Wartonah. 2010. Kebutuhan Dasar Manusia dan Proses Keperawatan. Jakarta : Salemba Medika.

Wiyoto, BT. 2011. Remedial Massage Panduan Pijat Penyembuhan Bagi Fisioterapis, Praktisi, dan Instruktur. Yogyakarta : Nuha Medika.

Zulmi, AZ, 2016. Pengaruh Masase Punggung Terhadap Kualitas Tidur Pada Lansia, UJ, 1-123. Diakses dari http://repository.unej.ac.id/handle/12345 $6789 / 76514$. 